\title{
Pengaruh Pendidikan Kesehatan Terhadap Pengetahuan dan Sikap Siswa SMP Dharma Pancasila Tentang Manajemen Kesehatan Menstruasi
}

\author{
Nur Asnah Sitohang ${ }^{1, a^{*}}$, Cut Adeya Adella ${ }^{2, b}$ \\ ${ }^{1}$ Fakultas Keperawatan, Universitas Sumatera Utara, Medan 20153, Indonesia \\ ${ }^{2}$ Fakultas Kedokteran, Universitas Sumatera Utara, Medan 20153, Indonesia \\ anur75asnah@yahoo.co.id*; bfauziahnasution@uinsu.ac.id* \\ * corresponding author
}

ARTICLE INFO

Keywords

Management of menstrual health

Junior high school students

Knowledge

Attitudes

\section{ABSTRACT}

Menstrual Hygiene Management (MHM) is the management of hygiene and health when women experience menstruation. The main problem in adolescents related to menstruation is the lack of knowledge about MSM and poor water sanitation. Many girls don't have the right understanding that menstruation is a normal biological process. Community service aims to improve students' knowledge and attitudes about menstrual health management. The method used is socializing; identify the state of menstrual health service facilities in schools: bathrooms, water, information; carry out bathroom renovations; provide educational media about menstrual health management in the form of posters, videos, leaflets, modules and flip sheets. Pre-test and post-test aims to identify students' knowledge and attitudes about menstrual health management. Analysis of the data used is the dependent $t$ test. The knowledge of students before being given health education majority was in the sufficient category and thereafter increased to good. Likewise, students' attitudes increase to be positive. The statistical test results obtained mean difference of 7.72 and $\mathrm{P}$ Value $=0.001$, it can be concluded that there is a significant effect of health education on knowledge. For attitudes the mean difference is 1.62 and the $\mathrm{P}$ value = 0.001 , it can be concluded that there is a significant influence on health education on student attitudes. Therefore it is suggested to the school to include this topic in the subject matter. So students can apply it early and their reproductive health can be maintained.

\section{Pendahuluan}

Manajemen Kesehatan Menstruasi (MKM) merupakan pengelolaan kebersihan dan kesehatan pada saat perempuan mengalami menstruasi. Perempuan pun harus dapat menggunakan pembalut yang bersih, dapat diganti sesering mungkin selama periode menstruasi, dan memiliki akses untuk pembuangannya, serta dapat mengakses toilet, sabun, dan air untuk membersihkan diri dalam kondisi nyaman dengan privasi yang terjaga.

Pokok permasalahan pada remaja terkait menstruasi ini adalah kurangnya pengetahuan mengenai MKM dan buruknya sanitasi air. Banyak anak perempuan tidak memiliki pemahaman yang tepat bahwa menstruasi adalah proses biologis yang normal. Mereka justru baru mengenalnya pada saat menarke alias saat pertama kali mengalami menstruasi. Hal ini diperburuk dengan fakta bahwa anak perempuan sering kesulitan membeli atau mendapatkan pembalut saat diperlukan. Penelitian UNICEF di Indonesia pada 2015 menemukan fakta 1 dari 6 anak perempuan terpaksa tidak masuk sekolah selama satu hari atau lebih, pada saat menstruasi [1]. 
Peristiwa menstruasi yang merupakan darah kotor, jika kurang dijaga kebersihannya akan berpotensi untuk timbul infeksi pada organ reproduksi Sedangkan apabila perilaku hygienis tersebut tidak dilakukan dan remaja putri kurang peduli akan kebersihan alat reproduksinya, tidak menjaga penampilan dan kesehatan sewaktu menstruasi, mereka dapat terkena kanker rahim, keputihan, mengurangi aktivitas saat menstruasi karena malas, kurang percaya diri, percaya akan mitos-mitos seputar menstruasi yang beredar di masyarakat, dijauhi teman-teman karena bau badan amis dan lainnya [2].

Berdasarkan data dari badan kesehatan Dunia (WHO), kanker serviks merupakan kanker nomor dua terbanyak pada perempuan berusia 15-45 tahun setelah kanker payudara. Tidak kurang dari 500.000 kasus baru dengan kematian 280.000 penderita terjadi setiap tahun di seluruh dunia. Indonesia berada pada peringkat pertama untuk kasus wanita penderita kanker serviks sedunia, sedangkan data dari Yayasan Kanker Indonesia, bahwa kanker serviks mengakibatkan korban meninggal dunia sedikitnya 555 wanita perharinya dan 200.000 wanita pertahunnya.

Menurut penelitian menyebutkan bahwa kanker ini disebabkan oleh virus Human Papilloma Virus (HPV) yang muncul antara lain karena perilaku sering berganti-ganti pasangan seks dan perilaku yang tidak higienis pada saat menstruasi. Oleh karena itu pada saat menstruasi seharusnya perempuan benar-benar dapat menjaga kebersihan organ reproduksi secara ekstra terutama pada bagian vagina, karena kalau tidak dijaga kebersihannya, akan menimbulkan mikroorganisme yang berlebih sehingga mengganggu fungsi organ reproduksi [3][4][5].

Penelitian Unicef pada tahun 2015 yang dilaksanakan pada 1402 peserta pada 16 sekolah di 4 provinsi di Indonesia, menyebutkan bahwa: a). ketidakcukupan pengetahuan tentang menstruasi, siklus menstruasi dan MKM berakibat pada kurangnya persiapan pada saat menstruasi pertama, miskonsepsi tentang pembuangan sampah pembalut, dan kurangnnya pengetahuan tentang bagaimana mengelola menstruasi dengan aman di sekolah. Sementara itu, ibu, teman, dan guru merupakan sumber informasi utama tentang menstruasi tetapi mereka tidak dapat memberikan informasi yang akurat dan menyeluruh tentangmenstruasi [6].

Keyakinan dan kepercayaan bahwa menstruasi itu kotor atau tidak bersih berdampak pada praktik MKM yang tidak didukung dengan fasilitas air, sanitasi, dan kebersihan di sekolah. Hampir semua remaja putri mengatakan mereka harus menyuci sampah pembalut sebelum dibuang, akan tetapi sebagian besar sekolah tidak menyediakan air yang cukup atau tempat tersendiri untuk praktik MKM tersebut. Terlebih lagi, hanya sedikit sekolah yang menyediakan tempat sampah untuk membuang pembalut di dalam toilet, dan remaja putri merasa malu saat membuang sampah pembalut [7].

Ketidakcukupan air, fasilitas sanitasi, dan kebersihan di sekolah juga menjadi tantangn bagi remaja putri yang sedang menstruasi. Selain ketidakcukupan air untuk mencuci, toilet yang kecil dan tidak bersih serta kurangnya privasi menyebabkan remaja putri enggan untuk mengganti pembalut di sekolah. Hampir semua fasilitas air, sanitasi dan kebersihan di sekolah tidak dapat diakses oleh siswa berkebutuhan khusus (cacat). Akibatnya, remaja putri terpaksa pulang kerumah untuk mengganti pembalut atau memakai kain selama lebih dari delapan jam dan itu dapat membuat alat kelamin iritasi dan gatal, juga mereka takut 'bocor' serta menodai pakaian [7].

\section{Metode}

Berdasarkan permasalahan yang telah dikemukakan, maka dalam kegiatan ini metode yang digunakan adalah melakukan sosialisasi kegiatan pada pihak sekolah; mengidentifikasi keadaan fasilitas pelayanan kesehatan menstruasi di sekolah: kamar mandi,air,informasi; melakukan kerjasama dengan kepala sekolah merenovasi kamar mandi; menyediakan media edukasi tentang manajemen kesehatan menstruasi berupa poster, video, leaflet, modul dan lembar balik; melakukan pre test tujuannya untuk mengidentifikasi pengetahuan dan sikap siswa tentang manajemen kesehatan menstruasi; melakukan Pendidikan kesehatan tentang manajemen kesehatan menstruasi; melakukan post test tujuannya untuk mengidentifikasi pengetahuan dan sikap siswa tentang manajemen kesehatan menstruasi. 


\section{Hasil dan Diskusi}

Tabel 1. Pengaruh pendidikan kesehatan terhadap pengetahuan siswa SMP Dharma Pancasila tentang manajemen kesehatan menstruasi

\begin{tabular}{ccccc}
\hline Variabel & Mean & SD & Beda mean & Nilai P \\
\hline Pengetahun: & & & & \\
& & & & \\
$-\quad$ sebelum & 19.91 & 4.41 & & \\
$-\quad$ setelah & intervensi & 29.63 & 0.97 & \\
\end{tabular}

Berdasarkan tabel 1 diperoleh data sebelum diberi pendidikan kesehatan rata - rata pengetahuan siswa 19.91 dan setelah 29.63. Hasil uji statistik diperoleh beda mean 7.72 dan nilai $\mathrm{P}=0,001$, maka dapat disimpulkan ada pengaruh yang signifikan pendidikan kesehatan terhadap pengetahuan siswa tentang manajemen kesehatan menstruasi.

Tabel 2. Pengaruh pendidikan kesehatan terhadap sikap siswa SMP Dharma Pancasila tentang manajemen kesehatan menstruasi $(n=140)$

\begin{tabular}{lllll}
\hline Variabel & Mean & SD & Beda mean & Nilai P \\
\hline Sikap: & & & & \\
$-\begin{array}{l}\text { sebelum } \\
\text { setelah } \\
\text { intervensi }\end{array}$ & 10.23 & 1.79 & 1.62 & 0,001 \\
& 11.86 & 0.46 & & \\
\hline
\end{tabular}

Berdasarkan tabel 2 diperoleh data sebelum diberi pendidikan kesehatan rata - rata sikap siswa 10.23 dan setelah 11.86. Hasil uji statistik diperoleh beda mean 1.62 dan nilai $\mathrm{P}=0,001$, maka dapat disimpulkan ada pengaruh yang signifikan pendidikan kesehatan terhadap sikap siswa tentang manajemen keshatan menstruasi.

\section{Pembahasan}

a. Perbedaan pengetahuan siswa tentang manajemen kesehatan menstruasi sebelum dan sesudah dilakukan pendidikan kesehatan

Menstruasi adalah proses biologis yang akan dialami oleh semua wanita ketika memasuki usisa remaja. Hal ini merupakan pengalaman yang signifikan dalam hidup mereka. Kebersihan selama menstruasi sangat penting unutk dijaga. Remaja wanita harus sudah dibekali pengetahuan tentang siklus menstruasi, menggunakan sabun dan air untuk membersihkan tubuh sesuai kebutuhan, dan harus memiliki akses ke fasilitas pembuangan pembalut yang telah digunakan. Manajemen kesehatan menstruasi di Indonesia dapat menjadi suatu tantangan. Dibutuhkan intervensi untuk meningkatkan pengetahuan para remaja.

Pengetahuan merupakan hasil dari tahu, yang terjadi setelah seseorang melakukan penginderaan terhadap suatu hal. Tingkat pengetahuan dipengaruhi oleh usia, tingkat pendidikan, sosial ekonomi, lingkungan pergaulan atau kelompok sebaya, dan paparan informasi [8]. Pengetahuan dapat diperoleh dari pendidikan, pengalaman diri dan orang lain, media massa maupun lingkungan. Pengetahuan atau kognitif merupakan domain yang sangat penting untuk terbentuknya tindakanseseorang.

Berdasarkan analisis kuesioner menunjukkan bahwa rata-rata pengetahuan siswa sebelum dilakukan pendidikan kesehatan adalah 19,91 (kategori cukup) dan rata-rata pengetahuan siswa setelah dilakukan pendidikan kesehatan adalah 29.63 (kategori baik). Pertanyaan yang paling banyak dijawab tidak tahu sebelum pendidikan kesehatan adalah pengertian manajemen kesehatan menstruasi (74.625), pengertian menarche $(89.55 \%)$, pengertian dishmenorea $(97,01 \%)$ dan siklus menstruasi $(98.50 \%)$. Berdasarkan hasil uji statistik diperoleh beda mean 7.72 dan nilai $\mathrm{P}=0,001$ ( $\mathrm{P}$ 
$<0,05)$, dengan demikian dapat disimpulkan bahwa ada pengaruh yang signifikan pendidikan kesehatan terhadap pengetahuan siswa tentang manajemen kesehatan menstruasi sebelum dan setelah diberikan pendidikan kesehatan.

Pengetahuan adalah hasil tahu dari manusia setelah melakukan penginderaan terhadap suatu objek tertentu sehingga seseorang mampu mengambil keputusan dan membentuknya menjadi suatu sikap. Peningkatan pengetahuan dan sikap setelah diberikan pendidikan kesehatan yang terjadi pada penelitian ini sesuai dengan teori yang dikemukakan oleh Notoadmojo (2007) yang menyebutkan bahwa pengetahuan akan membuat seseorang mampu mengambil keputusan. Pendidikan kesehatan seringkali mengalami kendala karena keterbatasan pengetahuan antara edukator dengan sasaran di mana bahasa dan logika yang dimiliki oleh edukator tidak sesuai dengan sasaran pendidikan. Selain itu topik yang tabu atau dianggap memalukan juga menjadi pembatas antara edukator dengan sasaran pendidikan.

Manajemen Kebersihan Menstruasi (MKM) merupakan pengelolaan kebersihan dan kesehatan pada saat perempuan mengalami menstruasi. Salah satu penyebab masalah kesehatan yang sering timbul pada remaja adalah personal hygiene yang buruk. Personal hygiene yang sehat saat menstruasi sangat penting dilakukan dalam upaya mencegah gangguan pada saat menstruasi. Tujuan dan manfaat perawatan diri yaitu meningkatkan derajat kesehatan seseorang, memelihara kebersihan diri seseorang, memperbaiki personal hygiene yang kurang, mencegah penyakit, menciptakan keindahan dan meningkatkan rasa percaya diri [7].

Berdasarkan penelitian Putri (2014) dijelaskan bahwa pengetahuan remaja puteri dalam merawat perineum saat menstruasi sebelum pendidikan kesehatan mayoritas terdapat pada kategori cukup dan sesuah pendidikan kesehatan pengetahuan menjadi kategori baik, hasil tersebut menunjukkan hasil yang signifikan. Hal yang sama juga terjadi pada keterampilan merawat perineum yang awalnya cukup baik menjadi baik dan menunjukkan hasil yang signifikan. Disimpulkan bahwa pendidikan kesehatan tentang hygiene saat menstruasi berpengaruh signifikan terhadap keterampilan remaja puteri dalam merawat perineum saat menstruasi [9].

b. Perbedaan sikap siswa tentang manajemen kesehatan menstruasi sebelum dan sesudah dilakukan pendidikankesehatan

Teori Green menyebutkan bahwa sikap merupakan faktor predisposisi yang mempengaruhi perilaku seseorang. Sikap adalah tanggapan batin terhadap rangsangan dari luar yang menghendaki respon individual sehingga timbul perasaan suka atau tidak suka. Sikap merupakan reaksi atau respon yang masih tertutup dari seseorang terhadap suatu stimulus atau objek. Pada saat haid perawatan menstruasi menjadi sangat penting karena pembuluh darah dalam rahim mudah terkena penyakit sehingga diperlukan perilaku hygiene yang baik.

Perilaku hygiene menstruasi adalah tindakan yang dilakukan untuk menjaga kebersihan daerah kemaluan selama menstruasi berlangsung. Perilaku buruk dalam menjaga kebersihan genitalia yaitu, jarang mengganti celana dalam, tidak sering mengganti pembalut dapat meningkatkan resiko infeksi pada vagina [10].

Berdasarkan hasil analisis kuesioner diperoleh nilai rata-rata sikap siswi sebelum diberi pendidikan kesehatan adalah 10.23 dan setelah diberikan pendidian kesehatan adalah 11.86. Hasil uji statistik diperoleh beda mean 1.62 dan nilai $\mathrm{P}=0,001$,maka dapat disimpulkan bahwa ada pengaruh yang signifikan pendidikan kesehatan terhadap sikap siswa tentang manajemen keshatan menstruasi. Perilaku dipengaruhi oleh Predisposing Factors, Reinforcing Factors, dan Enabling Factor. Salah satu faktor predisposing adanya perilaku personal hygiene yang sehat saat menstruasi adalah sikap yang mendukung terhadap perilaku tersebut. Dampak yang terjadi bila tidak menjaga kebersihan saat menstruasi akan rentan terjadi infeksi saluran kencing, infeksi saluran reproduksi, dan iritasi pada kulit.

Pendidikan kesehatan adalah semua kegiatan untuk memberikan dan atau meningkatkan pengetahuan, sikap, dan praktek baik individu, kelompok atau masyarakat dalam memelihara dan meningkatkan kesehatan mereka sendiri. Kurangnya informasi mengenai hygiene menstruasi dari tenaga kesehatan dan orang tua menyebabkan remaja mengalami ketidaktahuan mengenai teknik hygiene menstruasi. Perempuan harus dapat menggunakan pembalut yang bersih, dapat diganti sesering mungkin diri dalam kondisi nyaman dengan privasi yang terjaga [11].

Penelitian ini sejalan dengan penelitian Montgomery., dkk (2016) dilakukan pada remaja di Uganda, bahwa penyediaan pembalut dan pemberian pendidikan kesehatan dapat meningkatkan pengetahuan remaja. Penelitian Meinarisa (2017) menjelaskan pendidikan kesehatan menstrual higiene yang diberikan dilakukan dengan metode demonstrasi langsung dengan phantom dan media 
booklet yang menarik untuk kalangan remaja. Responden yang mengalami peningkatan pengetahuan menunjukkan bahwa pendidikan kesehatan yang diberikan dapat menghasilkan hasil yang efektif dikarenakan telah terjadi peningkatan pengetahuan dan pemahaman responden ( nilai $\mathrm{P}<0.05)$.Hasilpenelitian Pytagoras (2017) juga sejalan dengan penelitian ini bahwa dengan pemberian konselin informasi dan edukasi dapat meningkatkan perilaku remaja yaitu personal hygiene saat menstruasi dalam komponen kognitif berkriteria baik adalah 47 persen, komponen afektif berkriteria baik sebanyak 26 persen, dan komponen konatif berkategori kurang sejumlah 27persen. Media yang digunakan adalah posterdan leaflet [12][13].

\section{Kesimpulan}

Pendidikan kesehatan yang diberikan kepada siswa dapat meningkatkan pengetahuan dan sikapnya terhadap manajemen kesehatan menstruasi. Pengetahuan siswa sebelumnya dalam kategori cukup meningkat menjadi baik dan sikap siswa juga meningkat menjadi positif. Berdasarkan uji statistik dapat disimpulkan bahwa ada pengaruh yang signifikan pendidikan kesehatan terhadap pengetahuan dan sikap siswa tentang manajemen kesehatan menstruasi. Media pendidikan kesehatan yang digunakan efektif dalam meningkatkan pemahaman siswa.Mengingat pentingnya manajemen kesehatan menstruasi diberikan secara dini pada siswa maka disarankan kepada pihak sekolah memasukkan topik ini dalam materi pelajaran. Sehingga siswa secara dini dapat menerapkannya untuk menjaga kesehatan reproduksinya.

\section{Referensi}

[1] Van Leeuwen.C., Torondel.B. (2018). Improving menstrual hygiene management in emergency contexts: Literature review of current perspectives. International Journal of Women's Health Volume 10:169-186. April 2018

[2] Hardjito, dkk. (2010). Perbedaan Perilaku Menjaga Personal Hygiene Saat Menstruasi Pada Remaja Putri Antara Sebelum dan Sesudah Pemberian Penyuluhan Tentang Pendidikan Kesehatan Reproduksi. Jurnal Penelitian Kesehatan Forikes. Vol I No. 2. ISSN:2086-3098.

[3] Adinma, E.D. (2008). Perceptions and practise on menstruation amongst Nigerian secondary shool girls. Afr Reprod Health.2008:12(1):74-83)

[4] Kusmiran. E. (2011). Reproduksi Remaja dan Wanita. Jakarta: Salemba Medika.

[5] Bobak., Lowdermilk.., Jensen. (2004). Buku Ajar Keperawatan Maternitas (Edisi 4), Alih Bahasa Maria A.Wijayati, Peter I, Anugerah. Jakarta: EGC.

[6] Sinaga., dkk (2017). Manajemen Kesehatan Menstruasi. Jakarta.Universitas Nasional.

[7] Haver,J., Long, J. L. (2015). Save The Children Menstrual Hygiene Management: Operational Guidelines.

[8] Subhash B., dkk. (2011). Menstrual Hygiene Knowledge and Practice Among Adolescent School Girls of Saoner, Nagpur District. Journal of Clinical and Diagnostic Research,Vol5(5):1027-1033.

[9] Putri., dkk. (2014). Hubungan Pengetahuan dan Sikap terhadap Perilaku Personal Hygiene Menstruasi. Artikel Penelitian. Jurnal Ilmu Kesehatan Masyarakat Vol.5 No. 01 Maret 2016.

[10] Ratna, D.P. (2010). Pentingnya Menjaga Organ Kewanitaan, Jakarta: Indeks Media.

[11] UNICEF. (2015). Menstrual Hygiene Management in Indonesia: Understanding Practices, Determinants and Impacts among Adolescents School Girls. Melbourne: Burnet Institute.

[12] Montgomery., et all. (2016). Menstruation and the cycle property : a randomize control trial of sanitary pad and the puberity education provision in Uganda. PloS ONE 11 (12): e 0166122. Doi: 10.1371/journal.pone 0166122.

[13] Meinarisa (2017). Pengaruh Pendidikan Kesehatan Menstrual Hygiene (PMH) Terhadap Sikap Remaja Putri Dalam Menjaga Kebersihan Diri Selama Menstruasi. Journal endurance : Kajian Ilmiah Problema Kesehatan. Vol.4.(1). Februari. 2019 (141-149). 